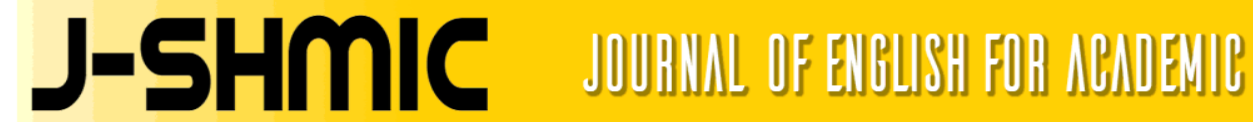

\section{FIELD TRIP STRATEGY IN ENHANCING WRITING DESCRIPTIVE TEXT}

\author{
Rugaiyah \\ Islamic University of Riau, Pekanbaru, Indonesia \\ email: ruqaiyah@edu.uir.ac.id
}

\begin{abstract}
Field-based learning has long been used by teachers to enhance students learning. Futher, Field trips are recognized as important moments in learning; a shared social experience that provides the opportunity for students to encounter and explore novel things in an authentic setting. The need to develop an effective environmental education program ranks as one of the major challenges facing education in the next decade. This paper is focused on analyzing the effectiveness of field trips strategy on students' writing descriptive text for a group of 30 students of second semester of FKIP UIR Pekanbaru in academic year 2016/2017 who were selected by using random sampling. The data were collected by giving test (pre-test and post-test) This study used experimental reseacrch, used by the Mann-Whitney $U$ t-test. The normality of the test was analysed through Kolmogorov-Smirnov ${ }^{\mathrm{a}}$. The instruments used in this study were lesson plans and writing descriptive text tests. Regarding the data analysis, mean, percentage and Mann-Whitney U test scores for the dependent sample were employed. The result of statistc indicated that the asymptotic significance of less than $0.05(\mathrm{p}=0.00<$ 0.05 ). it means the students' ability in writing descriptive text increased significantly after learning with fild trip strategy.
\end{abstract}

Keywords: fild trip, writing, descripive text

\section{STRATEGI FIELD TRIP DALAM MENINGKATKAN TEKNIK MENULIS DESKRIPTIF}

\begin{abstract}
Abstrak
Field-based learning telah lama digunakan oleh guru untuk meningkatkan pembelajaran para siswa. Selanjutnya, strategi field trip diakui sebagai momen penting dalam pembelajaran; Pengalaman bersosialisasi bersama yang memberikan kesempatan bagi siswa untuk menemukan dan mengeksplorasi halhal baru dalam suasana otentik. Kebutuhan untuk mengembangkan program pendidikan lingkungan yang efektif merupakan salah satu tantangan utama yang dihadapi pendidikan pada dekade berikutnya. Makalah ini difokuskan untuk menganalisis keefektifan strategi field trip pada penulisan teks deskriptif terhadap 30 mahasiswa semester dua FKIP UIR Pekanbaru pada tahun akademik 2016/2017 yang dipilih dengan menggunakan random sampling. Data diperoleh melalui tes (pre-test dan post-test) Penelitian ini menggunakan penelitian eksperimental, yang menggunakan uji Mann-Whitney U. Normalitas tes dianalisis melalui Kolmogorov-Smirnova. Instrumen yang digunakan dalam penelitian ini adalah rencana pelajaran dan penulisan teks deskriptif. Analisis data, mean,
\end{abstract}


persentase dan nilai uji Mann-Whitney U untuk sampel dependen digunakan. Hasil statistik penelitian ini menunjukkan bahwa the asymptotic significance lebih kecil dari pada $0.05(\mathrm{p}=0.00<0.05)$. Hal ini menunjukkan bahwa kemampuan siswa dalam menulis teks deskriptif meningkat secara signifikan setelah belajar dengan menggunakan strategi fild trip.

Kata kunci: field trip, menulis, teks deskriptif

\section{INTRODUCTION}

Teaching English as a second or foreign language has been a constant challenge due to the interference of the first language. Efforts to motivate learners must first look into the teaching methods among others, as implementing the conventional way of teaching English was found to be unmotivating. Especially when they are restricted to classroom learning which would expose them to a limited scope of knowledge, the situation does not reflect a positive trend in teaching and learning English.

One of the core subjects taught at schools up to universities is English Language. The Curriculum Specifications prescribed by the Ministry of Education specify the four skills which need to be mastered by the learners, namely listening, speaking, reading and writing. Writing is one of the skills which need to be mastered by the learners. Students learn different genres of writing like descriptive, expository, recount narrative, and others based on the prescribed syllabus of the Ministry of Education. There are many methods adopted by the teachers in teaching writing in the classrooms. One of the methods or strategies recommended in teaching writing descriptip text is field strip. As stated in the syllabus that the purpose of teaching descriptive text is to give information, the context of this text is description of particular thing, person, animal, place, and other.

Morever, The importance of teaching how to write descriptive paragraphs can be analyzed from to viewpoints: inside the classroom and outside the classroom. The freshmen are faced with the need of descriing events, experiences, areas, and objects inside the language classroom. No matter what the level is, students always ask about what they did during vacation, last night, in the morning or about their plans. They are also requested to provide a physical description of themselves and others. Outside the classroom, most freshmen supposed to put into practice all the knowledge that they have acquired in the English lessons. Nowadays, knowing how to write in English has become a transcendental feature of a 21 - century citizen. Students have to express themselves in English in writing to establish relationships with foreigners and people outside the country. Most of the time, students have to to describe events, experiences and so forth in their writing. Therefore, In writing that text, students need to observe things, place, and animals in their natural habitats. 
In order to create an efficient learning ambience, language teachers need to focus on the core principles of learning community which include integration of curriculum, active learning, student engage field-based learning has been used to generate student interest, enhance student learning, and help them acquire hands-on experience. Though mostly used in education, field-based learning, primarily field trips, can be useful in undergraduate and graduate education where students connect textbook and classroom learning with the real world.

The need to develop an effective environmental education program ranks as one of the major challenges facing education in the next decade. Learning can take place anywhere. Not only in the classroom or in school environment It could happen on the street, in the market place, in the place of worship, in the waters, in the space etc. This is not just talking about a particular type of education, it could be any type, formal, informal or non-formal education, it is all about learning generally. Field trips are recognized as important moments in learning; a shared social experience that provides the opportunity for students to encounter and explore novel things in an authentic setting. It is important to recognize that learning outcomes from field trips can range from cognitive to affective outcomes Heath, D,. (2012).

Previous research has highlighted the link between creativity and the natural world. For example, Mayer et al., (2009) considered the reason why nature can be beneficial to creation. In all three of their studies they discovered that exposure to the natural world enhanced the positive emotions of the participant as well as increasing their attention, motivation and the way the meditate and problem-solve. Alawad examined natural sound and whether this could be of benefit to the art classroom environment. She considered whether natural sound could foster creativity. This study found that natural sound in the art classroom enhanced students' creativity and raised students' marks in their art tasks (Alawad, 2012). Therefore, looking to the natural locations for field trips, such as a desert and outside space could stimulate a student's creativity and thirst for knowledge. This study will explore the role of field trips within the English curriculum. In particular, it will consider if field trips positively affect students' creative thinking and practices in writing descriptive text. As the aim of this research is to observe the subject in its natural state and possibly collect samples.

Field trips offer opportunities to students that they may not have known existed, and expose them to learning experiences that can not be duplicated inside the classroom. These "out-of-school" experiences have been a tradition since the earliest schools were founded.The outdoor field experience has traditionally been an important component in curricula. Students do seem to benefit from the learning experiences that occur outside the classroom and another key researcher into the area of field trips. Patrick, 2010, proposed 
that field trips should be weaved into the teaching schedule as this will provide an opportunity for students to view information for themselves and use their own senses to touch, or feel materials that they had previously only heard about (Patrick, 2010). This immediacy and accessibility is a key feature of field trips and one of its redeeming features. Leaving the school premises is a social experience and one, which provides a change of tempo and scenery for students. learn through their experiences and reflections. The fact that everything and every event of life provide information for education, justify teacher's effort to take student outside the four wall of the classroom for effective learning. This could be better explained in the values that educators attached to the relevant of field trip instructional strategy in the teaching and learning process. The traditional practice of field trip as an instructional strategy takes the students outside of the school environment. Thus field trip becomes a form of community contact instructional strategy adopted in the formal school system for the purpose of education.

Field trips are recognized as important moments in learning; a shared social experience that provides the opportunity for students to encounter and explore novel things in an authentic setting. Krepel and Durrall (1981) describe field trip as a school or class trip with an educational intent, in which students interact with the setting, displays, and exhibits to gain an experiential connection to the ideas, concepts, and subject matter. According to Oloyede, Ajibade and Bamidele (2006) field trip is the act of taking pupils out of the classroom into the community for the purpose of learning. Nabors, Edwards and Murray (2009) share the same view with the aforementioned authors that field trip is a type of experiential learning that gets children away from the traditional classroom setting and into a new mode of learning. Tal and Morag (2009) opinion is not differ from that of other scholars, they describe field trips as student experiences outside of the classroom at interactive locations designed for educational purposes. In view of this, the general perception of people as regard field trip is any teaching and learning process carried out by a group of people outside of the classroom environment.

The purpose of the trip is usually observation for education, experimental research or to provide students with experiences outside their everyday activities, such as going camping with teachers and their classmates.. Field trips are also used to produce civilized young men and women who appreciate culture and the arts. It is seen that moreadvantaged children may have already experienced cultural institutions outside of school, and field trips provide a common ground with more-advantaged and lessadvantaged children to have some of the same cultural experiences in writing descriptive text.

Field trips cannot replace school-based education but they should not have to compete to demonstrate their pedagogical worth. In formal education, learning outcomes are customarily pre-decided independently of the learner, for example through curricula and 
defined standards. In field trips, learners are invited to drive their own learning outcomes. Notwithstanding, the learning outcomes a field trip can impart are conditioned by the structure of the field trip, the personal context of children, the social context of the visit, the novelty of the physical context, teacher agendas and actions during the field trip, and the quality of preparations and follow-up experiences.

During the field trip it is possible that teachers divide learners into groups and assign them team tasks. When groups work together throughout a field trip, it improves learner communication with peers. Educational trips offer interaction and cooperation among students, teachers, other administrative staff and representatives at the field trip destination who offer guided tours and conduct question-and-answer sessions. In view of this learners expand their educational networks through interacting with others during field trips (Arduini, 2012). This social training also provide for the learners who came from different socialcultural background an opportunity of how to behave and control emotion in different situations (Shakil, Faizi \& Hafeez, 2011).

\section{Features of field trip \\ 1. Facilitate the learning of abstract concepts. Taking students on a field trip makes learning more effective as they will be able to gain vast ideas on the topic. \\ 2. Motivate students through increased interest and curiosity. Field trips can add variety to the regular}

classroom instructional program and they tend to be special and enjoyable learning experiences. As a result, students will develop positive attitudes in students toward related classroom activities.

3. Increases student-student and student-teacher social interaction.Field trips provide an opportunity to involve students, parents, and the teachers in the instructional program. Students can select the place to be visited, developing questions to ask, writing reports or thank you letters after the trip, or evaluating the experiences.

4. Develops social awareness. Field trips make students aware of learning activities in everyday life.

\section{Purpose of Field Trip}

1. It enhance the curriculum. Field trips are rich in educational possibilities as students learn from actual hands-on experiences, rather than by simply reading or hearing about something. Involvement in a real world experience makes learning more meaningful and memorable comparing to regular classroom instructional programs.

2. Give students experiential learning experiences. Involvement in a real world experience makes learning more meaningful and memorable. As a result the students will have more concept of the topic as they 
have learnt through their handon experiences.

3. Concrete skills such as note taking. Students have to develop questions to be asked, write reports or thank you letters after the trip, or evaluate their experiences. By doing such activities, students will develop various skills such as note taking skills, speaking skills, writing skills will enhance.

4. Involvement in a real world experience makes learning more meaningful and memorable

5. Field trips can add variety to the regular instructional program; they tend to be special and enjoyable learning experiences, ones which develop positive attitudes in students toward related classroom activities. Field trips are rich in educational possibilities because students learn from actual firsthand experiences, rather than by simply reading or hearing about something

6. Field trips help the students appreciate the relevance and importance of what they learn in the classroom.

\section{The procedure of field trip}

Myers and Jones (2009) describe that educational field trips should be designed around specific educational objectives. If a field trip not planned well in advance will end in confusion and will be a waste of time and money. So field trip should be planned as a cooperative activity involving full pupil participation under the teacher's supervision. When planning and organizing a successful field trip, three important stages should be included i.e. the pre-trip stage of a field trip involves two major components: administration and instruction. The second stage of a successful field trip is the trip itself. It has also two components: the role of the student and the role of the teacher. The third and final stage of a successful field trip is the post-trip stage which also consists of two components: debriefing and culminating activity.

\section{METHOD}

The population of this study was 180 second-year English mayor students in the fourth semester of academic year 2016/2017 at Islamic University of Riau Pekanbaru. The study sample consisted of two classes each consisting of 30 students selected by simple random sampling from seven classes. Therefore, The researcher took the experimental group on two separate field trips to the zoo and a museum. The field trips were each a day in length. The students in this group were also given writing materials and supplementary material prior to each trip. While, the control group of students (30 students) was not taken on these trips. This reseach consists of two variables, those are independent variable: field trips strategy and the dependent variable: the students' writing descriptive text.

Data were collected from the students' scores of the pre-test and post-test of writing descriptive text. The data obtained from this method of teaching in the study was analyzed and interpreted through quantitative 
analysis. Quantitative data includes the data obtained from the pre-test and the post-test. The t-test was to compare the students' writing descriptive text. When planning and organizing a successful field trip, three important stages should be included: pre-test, trip, and post-trip propossed by Myers (2015). The procedure of field trips followed in the teaching plan used in the study encompassed the following three stages:

\section{Procedure}

This study involved two groups those are experimental and control group. The main objective of such trips was to draw participants' attention to relevant aspects of the natural and social environment through determined activities. Morever, there were two destinations were recomended for the students to visit during this reseaarch; those were trips to the zoo and museum. The first week of the zoo trip, in a pre-trip the teachers talked about the zoo with her class, and she showed the students pictures of the animals they would be seeing. Activities for the pre-trip students focused on the different zoo animals. However, during the trip students exposed themselves to detected and described the animals found. All activities were performed in a cooperative in a their own group and playful way. All the participants were free to choose the animal they were interested in and wrote about the characteristics and the identification of the animals on their note. For the last trip (post-trip), they backed to the classroom and discussing about their finding during the trip. At the end of the class, they were asked to write a desciptive text about animal based on their experience during the trip. Therefore, It was expected that they could thus obtain integrated knowledge about the characteristics and the identification of animal. A special emphasis was put on the participants' sensory and emotional experience in contact with the environment.

After a two-day period of contact with the natural of animals, participants were taken to another place, that was in a museum, Taking a field trip to the Museum offers students and teachers an opportunity to interact with real objects. Field trips engage the senses, bring curriculum concepts to life, and inspire new questions. During the trip, they did the same activities when they were visiting the zoo. The Museum offers students a unique experience that cannot be replicated in the classroom. students engaged in the process of inquiry: asking questions, collecting evidence, and constructing explanations. Meanswhile, in the post-trip the students gathered into groups of three to four and made short oral reports and led discussions in the classroom and results from field obdervation. In addition, students were encouraged to discuss the field trip activities during the one hour bus rides between stops. The oral reports and discussions were intended to share information and reflections among the students before writing descriptive text. At the second session of the class, students were asked to generate their idea into a desriptive text based on their experience during the trips. They wrote three to four paragraph based on the generic structure of the 
descriptive text.in addition, the following day, the teacher corrected students' works by disdussing and solving problem. Consequently, field trip can foster students' criticalthinking skills: analyzing, reasoning, problem-solving, and creative thinking. Therefore, in a post trip students were asked to report they finding and write a descriptive text.

\section{FINDING AND DISCUSSION}

This research project was aimed at establishing whether field trip srategy could improve descriptive writing skills in a group of 30 students. Based on the analysis of the data and the findings the researcher states that students showed an improvement in their writing descripive text. as a result of the implementation of Process writing can be shown in the following table.

Table 1 The Normality of The Test

Tests of Normality

\begin{tabular}{|l|r|r|r|r|r|r|}
\hline & \multicolumn{3}{|c|}{ Kolmogorov-Smirnov $^{\mathrm{a}}$} & \multicolumn{3}{c|}{ Shapiro-Wilk $^{*}$} \\
\cline { 2 - 7 } & Statistic & \multicolumn{1}{c|}{$\mathrm{df}$} & \multicolumn{1}{c|}{ Sig. } & Statistic & \multicolumn{1}{c|}{$\mathrm{df}$} & \multicolumn{1}{c|}{ Sig. } \\
\hline Experimental Class & .144 & 30 & .117 & .945 & 30 & .126 \\
Control Class & .173 & 30 & .022 & .935 & 30 & .065 \\
Exsperimental Class & .174 & 30 & .022 & .921 & 30 & .028 \\
Contrrl Control & .219 & 30 & .001 & .888 & 30 & .004 \\
\hline
\end{tabular}

a. Lilliefors Significance Correction

Table 1 shows that only the data of experimental class is normally distributed $0.117>0.05$. Therefore, to determine whether the hypothesis shoud be rejected or not. This was tested at 0.05 level of significance. The decision role is such that null hypothesis $\left(\mathrm{H}_{0}\right)$ is rejected if the value of sig. (2-sided) is less that 0.05. the assence of the hypothesis is to determine the effectiveness of field trip strategy on tudents' writing descriptive text.

Table 2. Statistical Description of Field Trips and Conventional Strategies on Students' Writing Descriptive Text

\begin{tabular}{|l|r|r|r|r|r|}
\hline & Descriptive Statistics \\
& $\mathrm{N}$ & $\begin{array}{c}\text { Minimu } \\
\mathrm{m}\end{array}$ & $\begin{array}{c}\text { Maximu } \\
\mathrm{m}\end{array}$ & Mean & Std. Deviation \\
\hline $\begin{array}{l}\text { Pre-Tes of Eksperimen } \\
\text { class }\end{array}$ & 30 & 40.00 & 70.00 & 55.5000 & 8.64531 \\
Pre Control Class & 30 & 40.00 & 70.00 & 52.3333 & 8.48257 \\
Post Eksperimental Class & 30 & 60.00 & 90.00 & 76.1667 & 8.87493 \\
Post Control Class & 30 & 55.00 & 75.00 & 64.1667 & 4.56435 \\
Valid N (listwise) & 30 & & & & \\
\hline
\end{tabular}


Table 1 shows the statistical description of the pre and post test results of the two types instructional strategies on the students' writing descriptive text with conventional strategy pre-test Mean 52.333, field trip strategy pre-test Mean 55.5000, and conventional strategy post-test
Mean 64.1667, field trips strategy post-test Mean 76.1667. to determine if the observed effectiveness is significant at 0.05 level MannWhitney $\mathrm{T}$ test was used and the summary of the analysis is presented in table 3.

Table 3.Mann-Whitney U Test for the Descriptive Writing Text Test

Test Statistics $^{\mathrm{a}}$

\begin{tabular}{|l|r|}
\hline \multicolumn{1}{|l|}{} & \multicolumn{1}{|c|}{ nilai } \\
\hline Mann-Whitney U & 170.500 \\
Wilcoxon W & 635.500 \\
Z & -4.208 \\
Asymp. Sig. (2-tailed) & .000 \\
\hline \multicolumn{2}{|l|}{ a. Grouping Variable: class }
\end{tabular}

Table 3 shows results from the pre- and post-trip students, respectively. The asymptotic, twotailed significance (also known as the $-p \|$ value) generated from the MannWhitney U test. The asymptotic, twotailed significance is an indication of probability that the -null hypothesis\| cannot be rejected. The null hypothesis here is that the data from the independent samples come from the same population; in other words, the samples are not different from each other. Thus, a low value of the significance indicates that the null hypothesis can be rejected and the two samples are different from each other. The statements with the asymptotic significance of less than $0.05(\mathrm{p}=0.00<0.05)$.

From table 3 the result shows that there is a significant effect of field trip strategy on students' writing descriptive text with $0.00<0.05$. Futhermore, field trip enhance learners mental development through observation and offer opportunities to students to explore their ideas based on their own experience. In other research Mhgoub M Yassir (2014) agreed that field trips to natural and industrial locations were a beneficial learning aid and a means of fostering students' creativity and practices in art education. Obadiro (2016) virtual field trip and real field trip are effective strategies in enhancing students' knowledge in Social Studies. Haw-Jan “John” Wu (2009) Field trips do increase student interest in $\mathrm{OM}$ among other positive feelings of the students. When students have an interest, they tend to learn the subject materials better. 


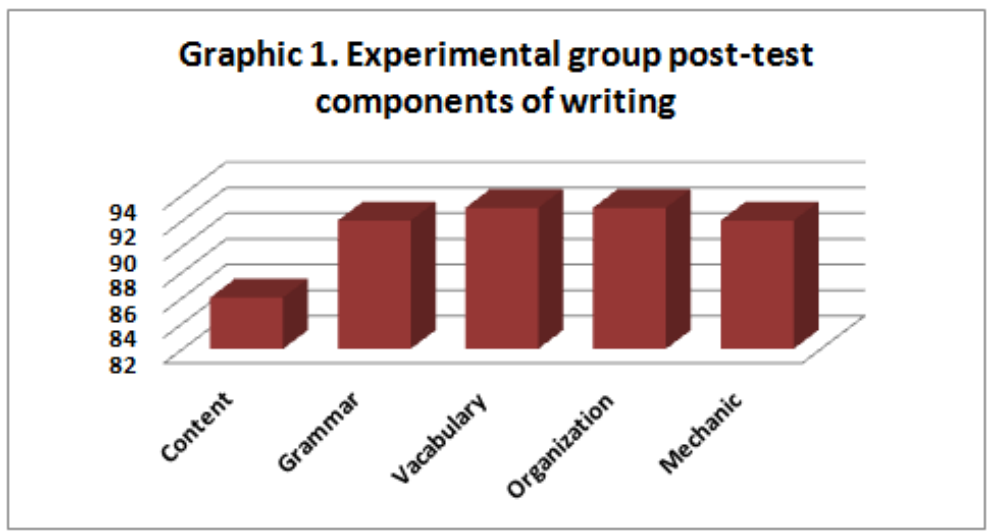

The graphic 1 illustrates experimental group's post-test evidanced that the higheast components score of writing were for vocabulary and organization (93), while the lowest was for content (86).

\section{CONCLUSION}

In conclusion, field trips strategy applied to Process approach was a suitable strategy for EFL students from the first grade at Islamic University of Riau Pekanbaru, Indonesia. to increase their writing descriptive text. In addition, this type of resources was a means for increasing students' motivation to improve and practice their descriptive writing text. . Even thought, the attained outcomes of this study reveal that subjects who were treated with field trips strategy prompts out performed students from the Control group who used the conventional strategy of writing. Moreover, It should also be noted that having students experience real-world activities outside of the classroom may have positive results not measured in this or any similar shortterm study. The majority of the related literature deals with the more general sphere of informal science education, which covers natural- or social-science-based learning activities such as short-term visits (hours to a day) to natural areas and more structured settings such as museums and zoos, aquaria, or gardens. Here, researcher reviews the informal science education literature with a focus on the effectiveness of informal science learning experiences on the students' writing descriptive text.

\section{REFERENCES}

Alawad, A. (2012). "Can we bring the natural environment into the art classroom? Can natural sound foster creativity?" Educational Research and Review Vol. 7 (28), pp. 627-631.

Behrendt, M. \& Franklin, T., (2014). A Review of Research on School Field Trips and Their Value in Education. International Journal of Environmental \& Science education 9, 235-245.

Haw-Jan "John" Wu (2009). Using field trips to enhance student learning in operations management: Literature Review and Field Observations. 
California State University San Bernardino, CA. California Journal of Operations Management (C) 2009 CSUPOM

Heath, D,. (2012). The Significance of Field Trips for Students. eHow online article. Retrieved on 21/01/2016 from http://www.ehow.com

Krepel, W. J., \& Durral, C. R., (1981). Field trips: A guideline for planning and conducting educational experiences. Washington, DC: National Science Teachers Association.

Mayer, S F, Frantz M C, Bruehlman, E. and Dolliver K. (2009). "Why Is Nature Beneficial? The Role of Connectedness to Nature Environment and Behavior". Volume 41, Number 5.

Mahgoub MYassir_ (2014) The Impact of Field Trips on Students' Creative Thinking And Practices In Arts Education: King Faisal University, Faculty of Education, Department of Art Education. Cited from http://www.jofamericanscience. org

Nabors, M.L., Edwards, L.C., \& Murray, R. K., (2009). Making the case for field trips:What research tells us and what site coordinators have to say. Education 129(4), 661-667.
Obadiora A. J. (2016) Comparative Effectiveness of Virtual Field Trip and Real Field Trip on Students' Academic Performance in Social Studies in Osun State Secondary Schools: Mediterranean Journal of Social Sciences MCSER Publishing, RomeItaly. ISSN 2039-2117 (online) ISSN 2039-9340 (print). Vol 7 No 1 January 2016.

Oloyede, E. O., Ajibade, Y. A. \& Bamidele, E. F., (2006). Choice and effective use of teaching methods. In Ehindero, O J. Dibu-ojerinde, O.O.and Ajibade, Y. A. Curriculum and the teaching process. Ghana, Dama Educational Services Ltd.

Patrick.O.A. (2010). "Effects of Field Studies on Learning Outcome in Biology", J Hum Ecol, 31 (3): 171-177.

Shakil, Faizi, Hafeez (2012) The Need and Importance of Field Trips at High Level in Kirachi, Pakistan. International Journal of Academic Research in Business and Social Sciences. June (2011) Vol. 2, No.1.

Tal, T., \& Morag, O., (2009). Reflective practice as a means for preparing to teach outdoors in an ecological garden. Journal of Science Teacher Education, 20(3), 245-262. 